\title{
Connecting With Latino Children: Bridging Cultural Gaps with Children's Literature
}

\author{
Sally Nathenson-Mejía \\ University of Colorado, Denver \\ Kathy Escamilla \\ University of Colorado, Boulder
}

\begin{abstract}
Teachers generally come out of teacher education programs with very little background in multicultural issues and instructional techniques. This study documents the use of Latino children's literature in field experience seminars to help preservice teachers (teacher candidates) gain background knowledge of the cultures, traditions, language, and issues surrounding Latinos in the United States and the elementary students with whom they will be working. The teacher candidates then use the same literature in their field experience classrooms, tapping into the children's funds of knowledge and encouraging the children to respond in a personal way. This experience enriches the teacher candidates' work with children and broadens their personal perspective and understanding of cultures different from their own. This study found that using Latino children's literature in a university teacher education program benefited both the preservice teachers and their students.
\end{abstract}

"So you are..."

“María Isabel Salazar Lopez," she replied...

"Ah, María Lopez," the teacher said as she read the card.

"We already have two Marías in this class. Why don't we call you Mary instead?" (Ada, 1993, p. 8) 


\section{Introduction}

Changing "foreign" names to make things more convenient has a long history in the United States. At the turn of the century, coming through Ellis Island, Chaims became Edwards, Rivkas became Ruths, and throughout U.S. schools in the 20th century countless Marías, Angélicas, and Franciscos became Marys, Angies, and Franks. As teachers, we realize that our students' names have special significance, and to change them arbitrarily devalues the children and their heritage. There is much more we need to understand about our students' backgrounds for, in fact, most of us who are teaching have grown up in cultures very different from those of the children we teach.

According to the U.S. Department of Education (2000), over 37\% of K-12 students are culturally, linguistically, and ethnically different from the dominant U.S. culture. Recent reports put the teaching population at $90 \%$ White, female, and middle class. If only $10 \%$ of teachers are linguistic and ethnic minorities and almost $40 \%$ of students are linguistic and ethnic minorities, it is clear that many thousands of students are being taught by teachers who have little or no background in the children's culture, language, traditions, and history. Whatever ethnicity they come from, teachers are finding themselves in schools where their own experiential background differs from that of their students (Grant \& Gomez, 2001; Taylor, 2000; Nieto, 2000). Teachers who are born in the United States and grow up in some strata of the middle class may have little in common with students of the same ethnicity who are immigrants or who grow up in lower socioeconomic status situations (Zeichner, 1993, in Taylor, 2000; Chávez Chávez, 1996). In discussing the use of multicultural literature in teaching, Taylor (2000) suggests, "Considering the current mismatch between students' and teachers' diversity, teachers may want to sensitize and expose their students and themselves to multiple perspectives and cultures of U.S. society" (p. 25).

We know that students must connect with teachers and the school culture if they are going to connect with school at all (Garcia, 1994). We have also seen that one characteristic of successful teachers is that they tend to know a great deal about their students' lives (Davis, Clarke, \& Rhodes, 1994). However, it is difficult for teachers to tap into children's extensive funds of knowledge (Moll, 1993) if they don't have any idea that those funds exist or how to access them. We believe strongly that educators can learn about the myriad cultures that make up our country's population and that it is imperative that all students and teachers, no matter their own ethnicity and culture, learn about as many other cultures, traditions, and histories as possible over the course of their education and professional careers. This can best begin by learning about the cultures and traditions of the children in their classrooms.

Using folk tales produced by mainstream and minority authors and publishers to teach about the cultures of various people has a firm foundation in the United States. Studies have been done on the use of multicultural children's literature in social studies venues to teach about multiculturalism 
and culture (Boyle-Baise, 1996; Mathis, 2001), and in teacher education courses to teach about the methodology of using children's literature and the power of diverse opinions (Roberts, Jensen, \& Hadjiyianni, 1997; Williams \& Owens, 1997). However, there has been little, if any, study on the use of children's literature of a specific ethnicity or culture to inform mainstream educators about their student constituents.

Being familiar with the impact that good children's literature has in elementary classrooms, we decided to use the growing number of Latino children's books as a teaching and learning vehicle for our preservice teachers (teacher candidates) to help them learn about and connect with the Latino children in their field placement schools.

In this article, we discuss how authentic ethnic literature can be used to help teachers and children truly connect by increasing teachers' understandings of the specific cultures of their students. The example we use is Latino children's literature and Latino students, but the same ideas and techniques can, and should, be used with all cultures and ethnicities. Unfortunately, as stated earlier, little research has been published on the use of ethnic literature as a bridge between preservice teachers and their students during field experiences. We hope this project will help to inform and encourage more such efforts.

We have found that most teachers come out of teacher education programs with very little background in multicultural issues and instructional techniques (Garcia \& Pugh, 1992; Villegas, 1996). For several years we have used Latino children's literature in various methods courses with our teacher candidates to help them gain background knowledge of the cultures, traditions, language, and issues surrounding the various Latino people in the United States. In turn, the teacher candidates use the same literature in elementary classrooms, encouraging the children to respond in a personal way. The experience enriches the teacher candidates' work with children and begins to broaden their perspective and understanding of cultures different from their own. This particular project was a part of seminars conducted within partner schools. The idea was to go beyond children's literature and language arts courses and bring the learning experience into the field experience itself.

This article explains the project we carried out over 3 years, the literature we used, the many issues that accompany this literature, and, finally, what we have learned so far and where we are going next.

\section{The Problem}

When our university's teacher education program began working with partner schools in 1993, the tremendous contrast in culture, language, traditions, and history between our teacher candidates and the students in the schools quickly became apparent. For example, several students communicated their concerns about being placed at inner-city schools where 
it might not be safe for them to park their cars on the street or leave the building after 6 p.m. Others expressed worries about working with students of limited English abilities. In addition, every year several students would try to establish their own field placements in suburban schools that were in middleand upper-class neighborhoods. How could we open the teacher candidates' minds and hearts to learning about, understanding, and caring for children whose lives were so different from their own?

It was not enough for teacher candidates to say they believed in equality, in educational opportunities for all, in tolerance of all people's beliefs and traditions. Research, and our own experience, has taught us that these professed beliefs on the part of teachers often lie at the surface and are easily dismissed when challenged (Chávez Chávez, 1996). A profound belief in pluralism and multiculturalism in education comes from facing and discussing challenging issues such as legal and illegal immigration, migrancy, language education, religious traditions, and the implications of valuing diversity. Such discussions must occur with their peers, professors, and cooperating teachers, and with the children.

\section{Profile of Preservice Teachers and Student Populations}

During the 3-year project, $76 \%$ of the teacher candidates we worked with were White. That means $24 \%$ were of other ethnic backgrounds, more than twice the national average. However, in real numbers we worked with a total of 70 teacher candidates, and only 16 of them were from linguistic and ethnic minority backgrounds. We had several teacher candidates whose families came from Mexico, South America, and Asia. Two candidates were originally from South America. Several spoke Spanish, either as their native or second language. No other languages were spoken by any of the teacher candidates. In the 3 years, only one candidate was African American. For the most part, those teacher candidates who spoke Spanish worked in bilingual classrooms, and the monolingual English-speaking teacher candidates worked in Englishlanguage classrooms. All of our university classes were conducted in English since the groups were always predominantly monolingual English.

Although we did not have access to the socioeconomic backgrounds of our students, this teacher licensing program is completely at the graduate level. Therefore, all the teacher candidates already held bachelor's degrees from a variety of institutions and had been accepted into a master's program for teacher licensing.

In contrast, this project was conducted in four elementary schools (all inner-city schools with Spanish-English bilingual programs) with Latino student populations of close to $70 \%$ or more. The free and reduced lunch rates in these schools were $60 \%$ to $80 \%$. Throughout each year, teacher candidates were placed in 7 to 10 classrooms in each school, half of which were bilingual classrooms. Not only did the Latino populations range from 
$68 \%$ to $87 \%$, every school also had children from various other ethnicities, cultures, and language backgrounds. Statistics on the immigrant status of families were not made available to us, but information from classroom teachers made it clear that many of the Latino and Asian families were recent immigrants.

\section{The Project}

Each year, we taught 22 to 26 teacher candidates (out of 80 to 90 elementary candidates in the university program) from late August through early May. The teacher candidates were placed in elementary classrooms throughout an entire school year. Once a month, they attended a 3-hour seminar with one of us. We decided to use Latino children's literature as a tool for discussing teaching strategies as well as increasing their background in and understanding of Latino culture. We had noticed during the first year of this project that the most common teaching strategy used with any literature was the "read aloud." We wanted to move teacher candidates beyond reading aloud, to encourage the use of more in-depth reading, writing, and discussion with children.

Specific techniques that we discussed in seminars and methods classes that became part of the teacher candidates' lessons included: literature circles, book units, authors' studies, poetry writing, reader's theater, content units, thematic units, and book review writing.

We also taught them about Latino children's literature, explaining terms and traditions with which they were unfamiliar. We looked at the illustrations in the books and compared them with traditional art from Latino countries. In addition, we brought up questions that would push them to think more deeply and confront some of the difficult cultural issues. For example, should you talk with Latino children about illegal immigration when some of their family members may be undocumented workers? Should teachers read books about the conflicts migrant children face such as frequent moving when many of the students and/or their families are in these same situations? And is it appropriate to read about curanderos [faith healers] when the use of these healers is not an accepted medical practice in the dominant U.S. culture, although it is a widespread practice in the community?

It should be noted that the seminars were all conducted in English, even though some of the students were reading and teaching in Spanish. Our groups were of mixed language abilities, but everyone was fluent in English, whether they were native speakers or not. This experience brought home to us the need to have a course available for those teachers who wanted to use and improve their Spanish proficiency. Thus, the course Literatura infantil en español [Children's Literature in Spanish] was created and has been received enthusiastically by area teachers. 


\section{Selection of the Literature}

We turned to children's literature to help us bring about these discussions because there is a growing number of excellent children's books that demonstrate various aspects of life for Latino children. We chose to focus our project on Latino children's literature because the majority of students in the schools we work with are Latino, and our own backgrounds are in the Spanish language and Mexican and Mexican American cultures. Further, we found a severe lack of Latino children's literature in the libraries and classrooms of schools in this study. Using suggestions from teachers, publisher catalogues, and visits to specialty bookstores, we selected 21 titles the first year and added 10 titles the second year. While looking for books we kept four criteria in mind: (a) country of origin; (b) language, that is, Spanish or English; (c) contemporary literature versus folk tales; and (d) high-quality text and illustrations. Each of these criteria, their implications, and examples will be discussed here.

Our first criterion, country of origin, for selecting the literature was important because most of the Latino student population in our area comes from families who have immigrated throughout the past 15 years from Mexico or who have been in the southwestern United States for several generations. Therefore, we looked for books written by Mexican and Mexican American authors and those coming from Mexican and Mexican American traditions. For example, we used two of the "Carlos" stories, Carlos y la milpa de maíz) Carlos and the Cornfield and Carlos y la planta de calabaza/Carlos and the Squash Plant by Jan Romero Stevens (1993a; 1993b); these stories are based on New Mexican Latino culture. We also used Cuadros de familia/Family Pictures by Carmen Lomas Garza (1990), whose background bridges Mexico and the United States. In addition, we used La mujer que brillaba aún más que el sol/The Woman Who Outshone the Sun (Cruz, 1991), a legend from Oaxaca, Mexico.

We also chose books with origins from other Latino countries, such as $E l$ sancocho de sábado/Saturday Sancocho (Torres, 1995) from Colombia and El tapiz de Abuela/Abuela's Weave (Castañeda, 1993) from Guatemala. We felt these books reflected experiences and values similar to the Mexican and Mexican American children's lives and literature. The concepts included in these books, such as extended family, going to the mercado [market], working to support family, and humor are reflective of the lives of the Mexican and Mexican American children with whom our preservice teachers work.

Our second criterion, language (i.e., Spanish or English), was important because about half of the teacher candidates were becoming bilingual teachers. Their school experiences were in bilingual classrooms. We wanted to provide opportunities for them to read in Spanish and to be able to use literature in Spanish with the children. We looked for books that had both Spanish and English versions or had both languages within one book since many of the teachers were not fluent in Spanish or did not speak Spanish at all. We were 
fairly successful; in the first year we found 14 books that were available in both languages, such as the "Carlos" books mentioned above. In the second year we added 6 more titles that came in both languages. We found that the teacher candidates with Spanish-speaking abilities were eager to read the books in Spanish and use them with their students in the schools. Those teacher candidates working only in English were also happy to have access to the Spanish books because many of their students, though learning in English, were also Spanish speakers.

However, we learned that there is a difference between books that are published with each language in its own edition and those in which the two languages are in the same book. When each language is in a different book, everything else remains the same: illustrations, format, and fonts. However, when both languages are in the same book, subtle differences make it difficult for some readers, usually those reading in Spanish. In most of the dual-language books, the Spanish is underneath the English, in a font (such as italics) that is more difficult for children to read and sometimes in a color (such as blue) that is more difficult to see. These differences, though they may appear to be insignificant, hinder the reading experience of the child reading in Spanish. The placement of Spanish below the English (as it was in most of the bilingual books) reinforces the lower status that Spanish occupies in the dominant U.S. culture (Shannon, 1995; Escamilla, 1994; Shannon \& Escamilla, 1999).

Also, we found that when both languages are on the same page, the reader naturally gravitates toward the language that is most comfortable; thus, when a native English speaker picks up a book, the tendency is to read in English. It is difficult to challenge yourself with a new language when the language you are proficient in is right there. We continue to select duallanguage books because of their excellent content and because without them, there would not be enough books to use. However, we have made the format of these books a point of discussion with teacher candidates. Their awareness of the inherent difficulties for young readers will help them create situations that support the reading experiences for their students.

Our third criterion, contemporary literature versus folk tales, is important because multicultural education has a long tradition of using folk tales to teach about various countries and cultures. We agree that folk tales are an essential component of culture, and we chose various folk tales to include in our selection. However, we feel strongly that contemporary literature based on people's lives (whether fiction or nonfiction) brings the teacher candidates closer to the real lives of the children they teach. It also brings them face to face with challenging issues we believe they must address. Many of the realistic fiction books deal with situations children must confront when they live in two cultural worlds: "It is important that our teacher candidates also understand that cultural conflict and negotiation are components of becoming bicultural" (Escamilla \& Nathenson-Mejía, in press). These issues include not having a permanent home (migrants), being an undocumented resident, being sick, having your name changed, feeling devalued by institutions such as 
school, moving from one country to another, serving as a translator between home and school, and growing up. We found that the teacher candidates sometimes had negative feelings about the books that contained these and other issues, and it was important for us to facilitate working through these feelings in constructive, in-depth discussions. Amigos del otro lado/Friends from the Other Side (Anzaldúa, 1993), El camino de Amelia/Amelia's Road (Jacobs, 1993), and El tapiz de Abuela/Abuela's Weave (Castañeda, 1993) are several such books. We chose 11 titles of contemporary literature the first year and 7 more titles the second year.

Our fourth criterion, high-quality text and illustrations, is important because research on children's literature stresses that we must demand high quality in the books we provide for children. Sims Bishop (1993) exhorts us to expect no less in multicultural children's literature. Criteria for high-quality children's literature can be found in various sources, including Huck, Hickman, Hepler, and Kiefer (2000); Taylor (2000); Harris (1993, 1997); Schon and Berkin (1996); and Cullinan (1987). Characteristics we looked for included: a) strong, believable story lines, well crafted, not contrived or condescending; b) believable, well-written language; and c) quality illustrations that matched and supported the story. We also looked for translations (whether from Spanish to English or English to Spanish) that represented conceptual equivalents (Barrera, 1992; Escamilla, Andrade, Basurto, \& Ruiz, 1996). We rejected books that we felt were stereotyping, condescending, or inaccurate.

We feel fortunate to have found as many books as we did that met our criteria, but we do not want our teacher candidates or our readers to get the impression that there are "enough." Although the number of Latino children's literature books being published is increasing, the total number of books is still small, as is true of all ethnic children's literature. We seek to impress upon our teacher candidates and their cooperating teachers that they must make their preferences known in the marketplace through the purchase of multicultural literature for use not just in the school library, but in classroom libraries as well. Also, we encourage teacher candidates to seek out and frequent specialty bookstores where they will find concentrations of books from particular ethnic groups and cultures.

\section{Results}

In the first year, we assigned the teacher candidates to read and respond to two to four books per month. With the support of two university grants, we purchased book sets of 10 so there would be enough books for literature study groups. They had time during the seminars to discuss the books in small groups, engaging in literature circles with their peers. We conducted whole group debriefings and worked through questions, concerns, and areas of conflict. (See Escamilla \& Nathenson-Mejía, in press, for further information on the responses.) We also encouraged them to use the books with the children in the partner schools, but we did not make this a required assignment. A few 
teacher candidates did use the books, but many of them did not, feeling too pressured by other assignments.

During the second and third years, we made using the books in their teaching a requirement. Along with reading the books and writing personal responses, they wrote three formal lesson plans (one in the fall and two in the spring) using the books, carried out the lessons with children, and then wrote a reflective summary of what they did and how it went. Teacher candidates appeared to truly enjoy the reading and the discussions, and they developed and carried out many excellent lessons and activities for the children.

One of our goals was to have teacher candidates use the literature to engage students in authentic literacy events (Edelsky \& Draper, 1989) and to foster meaningful discussions. Specifically, we wanted teacher candidates to use the books to create lessons that would achieve the following:

1. Create cultural connections between teacher candidates and their students.

2. Create connections between the books and children's lives (personal connections).

3. Enhance the verbal skills and abilities of their students in both Spanish and English.

4. Utilize literature to teach skills and strategies in reading and writing.

Teacher candidates' reflections on lessons they planned and taught demonstrated that they were beginning to connect with the children, and that the students were highly engaged in the literacy experiences. The following section discusses why the researchers chose these four goals and presents excerpts from teacher candidate reflections to support that these goals were achieved.

\section{Create Cultural Connections}

During Year 1, we learned that the teacher candidates do make connections to Latino children's literature. However, we were concerned that their connections were more general in nature than specifically cultural. For example, many of the teacher candidates related to the books with their own personal experiences with their names, their family's mobility, or strong ties to extended family, but they did not demonstrate that the books helped them to relate to their students culturally. We believe the teacher candidates' inability to make specific cultural connections stems from their lack of experience interacting with ethnic and linguistic minority cultures. This lack of experience was what prompted us to begin the study in the first place.

In order to increase cultural connections with the literature and with the children, during Years 2 and 3, we increased the amount of reading, held direct discussions in the seminars that broached cultural topics and difficult issues, required that all teacher candidates use the books with children in their field experiences, and required that they write reflections on the lessons they taught. 
The second group ... really engaged with the book [Lalo, Jimenez, 1995] from the start. They stopped me and asked questions, they told me stories about how they had eaten hot chilies, they told me if their parents are Mexican or American, they talked about everything on the discussion list. They liked that the boy ate the chili. (Teacher Candidate 1)

\section{Create Connections Between Books and Children's Lives}

In the first year, we saw that many teacher candidates were able to relate the books to something in their own lives, but they did not necessarily make connections between the books and their students' lives. Teacher candidate reflections revealed that in the second and third years, using Latino literature helped the teacher candidates to get students to make connections between the books and their lives.

One teacher candidate chose to do a book unit with a small group of native Spanish speakers on Cuadros de familia/Family Pictures (Lomas Garza, 1990). To get the students interested in the book, the teacher candidate had them think about family experiences. She told them they would compare their own family experiences to the ones in the book. After the teacher candidate read the book to the group, the students reread the book in pairs. As a group, they discussed the experiences from the book and compared these to their own experiences, then wrote and illustrated stories about one of their most memorable "family experiences." Finally, they compiled these experiences into their own class book. In reflecting on the book unit, the teacher candidate wrote:

I had never seen my students so excited about discussing something they had read. One student said he liked the book because it was about "real life." One student who hates to write, wrote a whole paragraph in about 10 minutes and eagerly shared it during author's chair time. The book unit went so well in Spanish that my Clinical Teacher asked me to repeat it with the English speakers. (Teacher Candidate 2)

The children's enthusiasm and the teacher candidate's reflection demonstrate that personal connections created by culturally familiar literature can be an effective means of engaging students in reading and writing.

\section{Enhance Verbal Skills and Abilities in Both Spanish and English}

Literature discussions are a wonderful teaching tool for using and improving students' verbal abilities (Daniels, 2002; Samway \& Whang, 1995). We encouraged the teacher candidates to pay attention to this as they taught lessons using the books.

After we read the book, La tortillería (Paulsen, 1995), I tried to engage the children in a book discussion. Since I know a lot of our students' parents work in factories and most are Mexican American, 
I decided to find out their opinion. I also thought that making tortillas was a theme that was familiar to most of the students and that they would be able to relate to the story. ... However ... our group was not accustomed to discussions about a book. They can answer questions about a book, but did not know how to state their opinion about the book. I had to explain what an opinion is and relate it to likes and dislikes. (Teacher Candidate 3)

Another teacher candidate had her native Spanish-speaking students read the book Pepita habla dos veces/Pepita Talks Twice (Dumas Lachtman, 1995), a story about a little girl who is tired of being bilingual because she has to translate for everyone, from her teacher, to shopkeepers in the community, to her own relatives (a common situation for first-generation children). After reading and sharing the book in Spanish, the students were so taken with it, the teacher candidate decided to make it into a reader's theater.

This third-grade class was being prepared to transition from Spanish to English reading. Using the students' prior knowledge from reading the book in Spanish, the teacher candidate prepared the reader's theater in English to be used as an English as a Second Language lesson and to give the children practice reading and speaking English. She reported that while these children were usually reluctant speakers of English, they loved doing this reader's theater in English.

\section{Teach Skills and Strategies in Reading and Writing}

Literature itself can be used to help students gain the skills and strategies they need to become effective readers. Lessons taught by the teacher candidates demonstrated that they were beginning to see how to use literature in this way.

I used the book Carlos and the Cornfield for an extended set of lessons with my first grade class. ... During writing time, I asked the students to write about something they had really wanted and what they did to get it. This topic did not really seem to interest them. If they were having a hard time, I said they could write about their favorite part in the book. This seemed to be easier for them. Finally, I asked the students to think of another story about Carlos. This was fun for them and they thought of some neat ideas. (Teacher Candidate 4)

My Name is María Isabel: The literature circle was implemented as group discussion and conversation about the book. ... I facilitated the students' learning process of using good reading strategies (prior knowledge, asking questions, making inferences, and predictions while reading) by modeling and giving voice support during shared reading ... and by engaging the students in stimulating discussions 
designed to activate their higher level thinking skills. (Teacher Candidate 5)

Another teacher candidate used Mi nombre es María Isabel/My Name is María Isabel (Ada, 1993) as the first book in an author study on Alma Flor Ada. She asked students to write letters to Dr. Ada. The teacher candidate used the preparation of these letters to help teach skills such as letter-writing format, capitalization and punctuation, and rules for accents. She noted that the children were enthusiastic about corresponding with the author. Further, since they were creating text through the letter writing, it was easy to identify topics for subsequent mini-lessons.

Although not all teacher candidates accomplished all of the four objectives each time they taught using the literature, it became apparent that we were making progress. The teacher candidates were able to get beyond simple "read alouds" and superficial discussions with their students. In addition, they saw firsthand the power of using relevant literature to excite and engage children in literacy experiences.

\section{Conclusion}

The project originally began because we wanted the teacher candidates to connect with their students, to begin to understand the children's cultural backgrounds, and to learn to teach literacy and content in meaningful ways. Latino children's literature became the vehicle we used to accomplish these goals. The teacher candidates' responses show that they were beginning to connect with their students. The Latino literature helped teacher candidates to see parallels, even superficial ones, in their own life experiences and in the lives of their students.

My family returned to a small Colorado town from southern California right before I went into high school.... My sister and I were very shy and these friends mistook this shyness for snobbishness because we were "California girls." (Teacher Candidate 6, responding to The Woman Who Outshone the Sun)

The activities that the teacher candidates engaged in using the literature increased their repertoire of methods and their confidence in going beyond "read alouds" in teaching.

[The students] were enthusiastic about doing literature circles. The discussion process was slower than I anticipated.... Towards the end of my student teaching, the students became better at beginning discussions. (Teacher Candidate 7)

We also saw a change in the teacher candidates' attitudes about and toward the children they were teaching and the communities in which they were working. Several teacher candidates became inspired to work on their Spanish by taking courses and participating in the School of Education's 
summer language and culture courses in Mexico. An even stronger demonstration of the attitude changes are the high numbers of students who sought and acquired positions in these four partner schools. Each of these four schools continues to have former teacher candidates as classroom teachers, even though two of the schools are no longer part of the partnership. The two schools that continue to work with the university have five to eight graduates of the program in various full-time positions. These former teacher candidates have become integral members of the communities, are strong proponents of the use of multicultural literature, and mentor current teacher candidates in the program.

The teacher candidates' personal responses, their lessons, and their accompanying reflective summaries demonstrate both the progress made and the need for further teaching. However, many questions remain unanswered. Were they able to go beyond a surface-level understanding of the children and their cultures? Are they continuing to inform themselves about the cultures of their students? Are they continuing to use ethnic literature as a means of connecting with their students and as a vehicle for teaching students? And are they using literature from a variety of cultures to teach their students about other cultures? We are in the process of gathering formal data on if and how our former teacher candidates are taking advantage of the experiences we gave them in order to improve our practices with current teacher candidates.

As teacher educators, we must continue to demonstrate for all our students, both preservice and experienced teachers, how to use ethnic literature in effective ways, as the focal point of a lesson, as supplemental resources, and as extensions. The more we engage our teacher candidates in the use of multicultural literature, the more natural it will become for them to seek out this literature as a teaching tool.

More importantly, we need to continue the work to bridge the gap between the cultures of teachers and the cultures of the children they teach. Exposing teachers to multicultural literature cannot be limited to specialty area seminars and children's literature courses. We must make greater efforts to incorporate the use of this literature into regular preservice methods courses and master'slevel courses for experienced teachers. At the same time, in order to push multicultural education beyond teaching about foods and holidays, we need to make sure preservice and experienced teachers are educated in the theories and methodologies of cultural pluralism, which, as Postman (1995) reminds us, shows us the substance and richness of each "tribal tale" and enriches our lives for knowing about them. 


\section{References}

Ada, A. F. (1993). Me llamo María Isabel [My name is María Isabel]. New York: Aladdin.

Anzaldúa, G. (1993). Amigos del otro lado [Friends from the other side]. San Francisco: Children's Book Press.

Barrera, R. (1992). The cultural gap in literature-based instruction. Education and Urban Society, 24, 227-243.

Boyle-Baise, M. (1996). Multicultural stocial studies: Ideology and practice. The Social Studies, 87(2), 81-87.

Castañeda, O. S. (1993). El tapíz de Abuela [Abuela's weave]. New York: Lee \&Low.

Chávez Chávez, R. (1996). Multicultural education in the everyday: A renaissance for the recommitted. Washington, DC: American Association of Colleges for Teacher Education.

Cruz, A. M. (1991). La mujer que brillaba aún más que el sol [The woman who outshone the sun]. San Francisco: Children's Book Press.

Cullinan, B. (1987). Children's literature in the reading program. Newark, DE: International Reading Association.

Daniels, H. (2002). Literature circles: Voice and choice in book clubs and reading groups. New York: Stenhouse.

Davis, A., Clarke, M., \& Rhodes, L. K. (1994). Extended text and the writing proficiency of students in urban elementary schools. Journal of Educational Psychology, 86(4), 556-566.

Department of Education, Office of Education Research and Information. (2000). The condition of education. Department of Education Statistics. Washington, DC: Author.

Dumas Lachtman, O. (1995). Pepita habla dos veces [Pepita talks twice]. Houston: Piñata Books.

Edelsky, C., \& Draper, K. (1989). Reading/ "reading”; writing/ "writing”; text/ "text." Reading-Canada, 7(3), 201-216.

Escamilla, K. (1994). The sociolinguistic environment of a bilingual school. Bilingual Research Journal, 18(1\&2), 21-48.

Escamilla, K., Andrade, A., Basurto, A., \& Ruiz, O. (1996). Instrumento de observación de los logros de la lecto-escritura inicial. Portsmouth, $\mathrm{NH}$ : Heinemann.

Escamilla, K., \& Nathenson-Mejía, S. (in press). Changing hearts and minds:Using Latino children's literature with preservice teachers.

García, E. (1994). Understanding and meeting the challenge of student cultural diversity. Boston: Houghton-Mifflin. 
García, J., \& Pugh, S. L. (1992). Multicultural education in teacher preparation programs: A political or an educational concept? Phi Delta Kappan, 74, 214-219.

Grant, C. A., \& Gomez, M. L. (2001). Journeying toward multicultural and social reconstructionist teaching and teacher education. In C. A. Grant and M. L. Gomez (Eds.), Making school multicultural: Campus and classroom (pp.3-16). Columbus, OH: Merrill.

Harris, V. (Ed.). (1993). Teaching multiethnic literature in the K-8 classroom. Norwood, MA: Christopher-Gordon.

Harris, V. (Ed.). (1997). Using multiethnic literature in the K-8 classroom. Norwood, MA: Christopher-Gordon.

Huck, C., Hickman, J., Hepler, S., \& Keifer, B. (2000). Children's literature in the elementary school. New York: McGraw Hill.

Jacobs, L. (1993). El camino de Amelia [Amelia's road]. New York: Lee \& Low.

Jimenez, E. (1995). Lalo . . and the red hot chile pepper. Cooper City, FL: Span-Press.

Lomas Garza, C. (1990). Cuadros de familia [Family pictures]. San Francisco: Children's Book Press.

Mathis, J. B. (2001). Respond to stories with stories: Teachers discuss multicultural children's literature. Social Studies, 92(4), 155.

Moll, L. (1992). Funds of knowledge for teaching: Using a qualitative approach to connect homes and classrooms. Theory into Practice, 31(1), 132-41.

Nieto, S. (2000). Affirming diversity. Boston: Allyn \& Bacon..

Paulsen, G. (1995). La tortillería [The tortilla factory]. San Diego: Harcourt, Brace.

Postman, N. (1995). The end of education. New York: Random House.

Roberts, S. K., Jensen, S. J., \& Hadjiyianni, E. (1997). Using literature study groups in teacher education courses: Learning through diversity. Journal of Adolescent \& Adult Literacy, 41(2), 124-134.

Samway, K. D., \& Whang, G. (1995). Literature study circles in a multi-cultural classroom. New York: Stenhouse.

Schon, I., \& Berkin, S. C. (1996). Introducción a la literature infantily juvenil. Newark, DE: International Reading Association.

Shannon, S. (1995). Culture of the classroom: Socialization in an urban bilingual classroom. The Urban Review, 27(4), 321.

Shannon, S., \& Escamilla, K. (1999). Mexican immigrants in the United States: Targets of symbolic violence. Educational Policy, 13(3), 347-370.

Sims Bishop, R. (1993). Multicultural literature for children: Making informed choices. In V. Harris. (Ed.), Teaching multicultural literature in grade $K-8$. Norwood, MA: Christopher-Gordon. 
Stevens, J. R. (1993). Carlos y la milpa de maíz [Carlos and the cornfield]. Flagstaff, AZ: Northland.

Stevens, J. R. (1993). Carlos y la planta de calabaza [Carlos and the squash plant]. Flagstaff, AZ: Northland.

Taylor, S. (2000). Multicultural is who we are: Literature as a reflection of ourselves. Teaching Exceptional Children, 32(3), 24-29.

Torres, L. (1995). El sancocho del sábado [Saturday sancocho]. New York: Farrar Straus.

Villegas, A. M. (1996, Winter). Educating teachers for cultural diversity. Paper pre-sented at the annual meeting of the American Association of Colleges for Teacher Education, Chicago.

Williams, N. S., \& Owens, R. F. (1997). Benefits of using literature discussion groups in teacher education courses. Education, 117(3), 415-419. 